\title{
Alpha Tocopherol Application as Seed Priming Alters Antioxidative Defense System of Okra Against Salinity Stress
}

\author{
Maria Naqve', Muhammad Shahbaz ${ }^{1}$, Mehwish Naseer ${ }^{2}$, Athar Mahmood ${ }^{3 *}$ \\ ${ }^{1}$ Department of Botany, Faculty of Sciences, University of Agriculture Faisalabad, Faisalabad, Punjab, Pakistan \\ ${ }^{2}$ Department of Botany, Faculty of Science and Technology, Govt. College Women University Faisalabad, \\ Faisalabad, Punjab, Pakistan \\ ${ }^{3}$ Department of Agronomy, Faculty of Agriculture, University of Agriculture Faisalabad, \\ Faisalabad, Punjab, Pakistan
}

Received: 5 October 2020

Accepted: 3 December 2020

\begin{abstract}
Priming with antioxidants like $\alpha$-tocopherol is a pragmatic method to alleviate salinity effects. In this study, seeds of two okra varieties (Noori and Sabzpari) were primed for $16 \mathrm{~h}$ before sowing with $\alpha$-tocopherol levels [0 (distilled water), 100, 200 and $300 \mathrm{mg} \mathrm{L}^{-1}$ ] and salinity levels $(0$ and $100 \mathrm{mMNaCl})$ were maintained after sowing the seeds in plastic pots. Salt stress reduced the fresh biomass and yield while, increased the antioxidants activities(CAT, GPX, SOD and protease) total soluble sugars, reducing sugars, $\mathrm{MDA}, \mathrm{H}_{2} \mathrm{O}_{2}$, total soluble proteins, glycinebetaine and free proline contents of tested okra varieties. Whereas non-significant effect of salinity was recorded for non-reducing sugars, ascorbic acid, total phenolics and activity of POD in tested okra varieties. Alpha tocopherol seed priming proved effective in improving root and shoot fresh biomass, yield, sugars, total soluble proteins, glycinebetaine content and activities/concentration of antioxidants (ascorbic acid, total phenolics, GPX, SOD and protease) in both tested varieties under saline regime. Though, no significant alteration was observed on the concentration of MDA, $\mathrm{H}_{2} \mathrm{O}_{2}$ and free proline content due to alpha tocopherol seed priming treatment. Among all $\alpha$-tocopherol levels used inclusively 200 and $300 \mathrm{mg} \mathrm{L}^{-1}$ were more active. In addition, variety Noori performed better than Sabzpari in all traits.
\end{abstract}

Keywords: priming, Alpha tocopherol, antioxidants, okra, salinity 


\section{Novelty Statement}

We did novel work on Alpha tocopherol application as seed priming agent to boost up antioxidative defense system of two okra varieties against salinity stress which has not yet reported. Therefore, this important aspect is investigated to help the farmer for growing abovementioned varieties to mitigate the stress conditions.

\section{Introduction}

Okra is a warm season important vegetable crop grown worldwide [1]. It serves as good source of carbohydrates and mineral nutrients along with linoleic acid [2]. Fruits and leaves of okra are also rich source of mucilage, possessing medicinal and antioxidative properties [2]. Despite having high nutritional value, its successful production is affected by drastic effects of soil and water salinization [3]. Salinity directly impacts growth attributes and physiological processes, ultimately affecting whole plant [4]. Salt stress may shunt oxidation by inducing reactive oxygen species (ROS) [5]. These toxic oxygen radicals cause degradation of plastids and macromolecules [6] Production and accumulation of various antioxidants is plants adaptation to manage with ROS induced oxidation [7]. Additionally, upregulation of non-enzymatic antioxidants under oxidative stress quench ROS [8]. Priming with antioxidants is a pragmatic approach to combat salinity induced oxidative stress [9], that allows pre-germination metabolism [10]. Salinity tolerance is linked with improved sugars metabolism [6]. Increased accumulation of antioxidants combat environmental stresses by enhanced cellular homeostasis [11].

Chloroplasts and plastoglobuli are the main sites for the synthesis of $\alpha$-tocopherol [12]. As ROS are synthesized in chloroplasts [13], thus alpha tocopherol being produced in chloroplasts can quench ROS. Tocopherols as antioxidantsplay vital role in stressed plants by scavenging ROS, as only single molecule of tocopherolmay scavenge about120 singlet oxygen molecules $\left({ }^{1} \mathrm{O}_{2}\right)$ [7]. Alpha tocopherol has evolved protective defense system in plants to combat salinity induced oxidants by over synthesis of peroxidase, catalase and proline $[14,15]$. In over all, $\alpha$ - tocopherol accumulates in the seeds during germination and shield the plants from salinity stress by constraining seed dormancy, dehydration and lipid peroxidation [16]. It also terminates chain reaction of polyunsaturated fatty acid radicals produced during lipid peroxidation by reducing MDA content [13]. We assumed that $\alpha$-tocopherol seed priming may improve salinity tolerance in okra by boosting antioxidative potential. The current study was thus, conducted to explore that $\alpha$-tocopherol seed priming could be effective strategy against salinity in okra.

\section{Materials and Methods}

The current study was performed twice in the Old Botanical Garden at University of Agriculture Faisalabad, Pakistan. Seeds of two okra varieties were obtained from Ayub Agricultural Research Institute (AARI), Faisalabad, Pakistan. Seeds of tested okra varieties (Noori and Sabzpari) were soaked for $16 \mathrm{~h}$ in varying levels of $\alpha$-tocopherol solution [0, 100, 200 and $\left.300 \mathrm{mg} \mathrm{L}^{-1}\right]$. After soaking seeds were blot dried before sowing. Seeds were sown in sand filled pots [Radius $(25 \mathrm{~cm})$ and depth $(29 \mathrm{~cm})$ ] containing $10 \mathrm{~kg}$ dry river sand, which was thoroughly washed. In each pot, 6 plants were maintained after thinning. Each pot was supplied with two liters (full strength) Hoagland's nutrient solution [17] every week till the termination of trial. Experiment was set up incompletely randomized design under factorial arrangement with four replicates. Salinity levels $(0$ and $100 \mathrm{mM} \mathrm{NaCl})$ were established and maintained during the experiment. The $100 \mathrm{mMNaCl}$ level was established by adding $50 \mathrm{mM} \mathrm{NaCl}$ aliquot with interval of 2 days to prevent the salt shock for plants. The Hoagland's nutrient solution (non-saline) and $100 \mathrm{mM} \mathrm{NaCl}$ along with Hoagland's nutrient solution (saline) were applied (2 L) per pot with interval of 10 days up to crop maturity. Two plants were uprooted from each pot four weeks after salinity treatment, washed away, and data were recorded for fresh biomass immediately. Additionally, data for the following physiological attributes were also analyzed.

\section{Total Soluble Sugars}

Procedure of Dubois et al. [18] was followed. Reaction mixture was prepared by adding $(1 \mathrm{~mL})$ sample, 5\% phenol solution and96\% sulphuric acid, absorbance was measured by using IRMECO-U2020 spectrophotometer.

\section{Reducing Sugars}

By following Miller [19] homogenate was prepared, and absorbance was measured by using IRMECO-U2020 spectrophotometer.

\section{Total Phenolics}

Fresh leaf $(0.5 \mathrm{~g})$ was standardized with $80 \%$ acetone, after centrifugation homogenate was made and reading was noted at $280 \mathrm{~nm}$, following Ainsworth and Gillespie [20].

\section{Ascorbic Acid}

Leaf sample $(0.5 \mathrm{~g})$ was standardized with 6\% trichloroacetic acid (TCA). Extract was then homogenized with $2 \mathrm{~m} \mathrm{~L}$ of 2, 4 dinitrophenyl hydrazine 
and 1 drop of $10 \%$ thiourea and observations were noted by following Mukherjee and Choudhuri [21].

\section{Hydrogen Peroxide $\left(\mathrm{H}_{2} \mathrm{O}_{2}\right)$ Content}

The procedure ascribed by Alexieva et al. [22] was adopted. Under chilled conditions $(0.5 \mathrm{~g})$ fresh leaf material was standardized with TCA then, homogenized with (5 mL) (TCA), (2mL) KI and K-phosphate buffer $(100 \mathrm{mM})$ and OD was taken at $390 \mathrm{~nm}$.

\section{Malondialdehyde (MDA) Content}

Ascribed procedure of Heath and Packer [23] was followed with slight modifications [24, 25]. Half $\mathrm{g}$ of fresh leaf material was digested with $(20 \%)$ TCA and $(0.5 \%)$ tetra butyric acid (TBA), then observations were recorded using IRMECO-U2020 spectrophotometer.

\section{Total Soluble Proteins}

Plant leaves (fresh) were crushed with potassium phosphate buffer in chilled environment, the extract $(5 \mu \mathrm{L})$ was then standardized with Bradford Dye and $0.1 \mathrm{~N} \mathrm{HCl}$ according to Bradford [26].

\section{Total Free Proline}

The protocol ascribed by Bates et al. [27] was followed to estimate the free proline from leaves and fruit material. Fresh leaves and fresh green pod materials (0.5) were separately homogenized with sulfo-salicylic acid and optical density was recorded at $520 \mathrm{~nm}$.

\section{Glycinebetaine (GB)}

By proposed method of Grieve and Grattan [28] glycinebetaine content was estimated from fresh leaves and fruit tissue. Homogenate was treated with $\mathrm{HCl}$, potassium tri-iodide and 1-2 dichloroethane in different steps and reading was noted at $365 \mathrm{~nm}$.

\section{Enzyme Extraction}

Fresh plant sample was standardized potassium phosphate buffer, after centrifugation, activities of following enzymatic antioxidants were recorded from supernatant.

Table 1. Analysis of variance (Mean squares) for growth, sugars and antioxidants activities of okra (Abelmoschusesculentus (L.) Moench) treated with different levels of $\alpha$-tocopherol as seed priming under control and saline conditions.

\begin{tabular}{|c|c|c|c|c|c|c|}
\hline Source & $\mathrm{Df}$ & $\begin{array}{l}\text { Shoot fresh } \\
\text { weight }\end{array}$ & Root fresh weight & Total soluble sugars & Reducing sugars & $\begin{array}{l}\text { Non-reducing } \\
\text { sugars }\end{array}$ \\
\hline Varieties (V) & 1 & $26.29 * * *$ & $0.24 *$ & $80.43 * * *$ & $4.33 * *$ & $47.41 * * *$ \\
\hline Salinity (S) & 1 & $218.59^{* * *}$ & $1.42^{* * *}$ & $27.67 * * *$ & $5.66^{* * *}$ & $8.29 \mathrm{~ns}$ \\
\hline $\begin{array}{l}\alpha \text {-tocopherol } \\
(\alpha \text {-toc })\end{array}$ & 3 & $11.32 * * *$ & $0.31 * * *$ & $37.25 * * *$ & $1.32 *$ & $37.76^{* * *}$ \\
\hline $\mathrm{V} \times \mathrm{S}$ & 1 & $4.73 \mathrm{~ns}$ & $0.003 \mathrm{~ns}$ & $4.82 \mathrm{~ns}$ & $1.21 \mathrm{~ns}$ & $1.20 \mathrm{~ns}$ \\
\hline $\mathrm{V} \times \alpha$-toc & 3 & $0.63 \mathrm{~ns}$ & $0.02 \mathrm{~ns}$ & $21.53^{* * *}$ & $1.05 \mathrm{~ns}$ & $16.68 * * *$ \\
\hline$S \times \alpha$-toc & 3 & $2.47 \mathrm{~ns}$ & $0.03 \mathrm{~ns}$ & $12.87 * * *$ & $0.54 \mathrm{~ns}$ & $15.04 * * *$ \\
\hline $\mathrm{V} \times \mathrm{S} \times \alpha$-toc & 3 & $0.56 \mathrm{~ns}$ & $0.01 \mathrm{~ns}$ & $11.41 * *$ & $0.25 \mathrm{~ns}$ & $14.12 * * *$ \\
\hline Error & 48 & 1.76 & 0.05 & 1.79 & 0.41 & 2.20 \\
\hline Source & $\mathrm{df}$ & Catalase (CAT) & $\begin{array}{c}\text { Guaicol peroxidase } \\
\text { (GPX) }\end{array}$ & $\begin{array}{l}\text { Peroxidase } \\
\quad \text { (POD }\end{array}$ & $\begin{array}{c}\text { Superoxide dismutase } \\
\text { (SOD) }\end{array}$ & Protease \\
\hline Varieties (V) & 1 & $2756.25 * * *$ & $1201818.9 * * *$ & $0.56 \mathrm{~ns}$ & $62868.43 * * *$ & $1196289.1 * * *$ \\
\hline Salinity (S) & 1 & $2500 * *$ & $1311689.2 * * *$ & $0.02 \mathrm{~ns}$ & $7086.33 *$ & $474376.56^{* * *}$ \\
\hline $\begin{array}{c}\alpha \text {-tocopherol } \\
(\alpha \text {-toc })\end{array}$ & 3 & $362.5 \mathrm{~ns}$ & $164776.57 * *$ & $1.24 \mathrm{~ns}$ & $10913.7 * * *$ & $306572.4 * * *$ \\
\hline $\mathrm{V} \times \mathrm{S}$ & 1 & $6.25 \mathrm{~ns}$ & $73048.57 \mathrm{~ns}$ & $0.24 \mathrm{~ns}$ & $1652.82 \mathrm{~ns}$ & $395326.56^{* * *}$ \\
\hline $\mathrm{V} \times \alpha$-toc & 3 & $60.41 \mathrm{~ns}$ & $3246.20 \mathrm{~ns}$ & $0.17 \mathrm{~ns}$ & $1687.76 \mathrm{~ns}$ & $72201.56^{*}$ \\
\hline $\mathrm{S} \times \alpha$-toc & 3 & $137.5 \mathrm{~ns}$ & $12766.95 \mathrm{~ns}$ & $0.22 \mathrm{~ns}$ & $3632.81 *$ & $58655.72 *$ \\
\hline $\mathrm{V} \times \mathrm{S} \times \alpha$-toc & 3 & $43.75 \mathrm{~ns}$ & $52232.986 \mathrm{~ns}$ & $0.07 \mathrm{~ns}$ & $1079.41 \mathrm{~ns}$ & $53780.72 \mathrm{~ns}$ \\
\hline Error & 48 & 206.25 & 32821.83 & 0.45 & 1128.77 & 19942.18 \\
\hline
\end{tabular}

$*, * *, * * *$ Significant at $0.05,0.01$ and 0.001 levels respectively; $\mathrm{ns}=$ non-significant. 
Superoxide Dismutase (SOD)

Procedure of Giannopolitis and Ries [29] was used for the measurement of SOD activities. Observations were recorded after placing reaction mixture under luminous lamp for 15 mins.

\section{Catalase (CAT) and Peroxidase (POD)}

Reaction mixtures were prepared separately for both enzymes and optical densities were recorded at $240 \mathrm{~nm}$ for CAT and at $470 \mathrm{~nm}$ for POD after every $30 \mathrm{~s}$ for 1 min according to the protocol of Chance and Maehly [30].

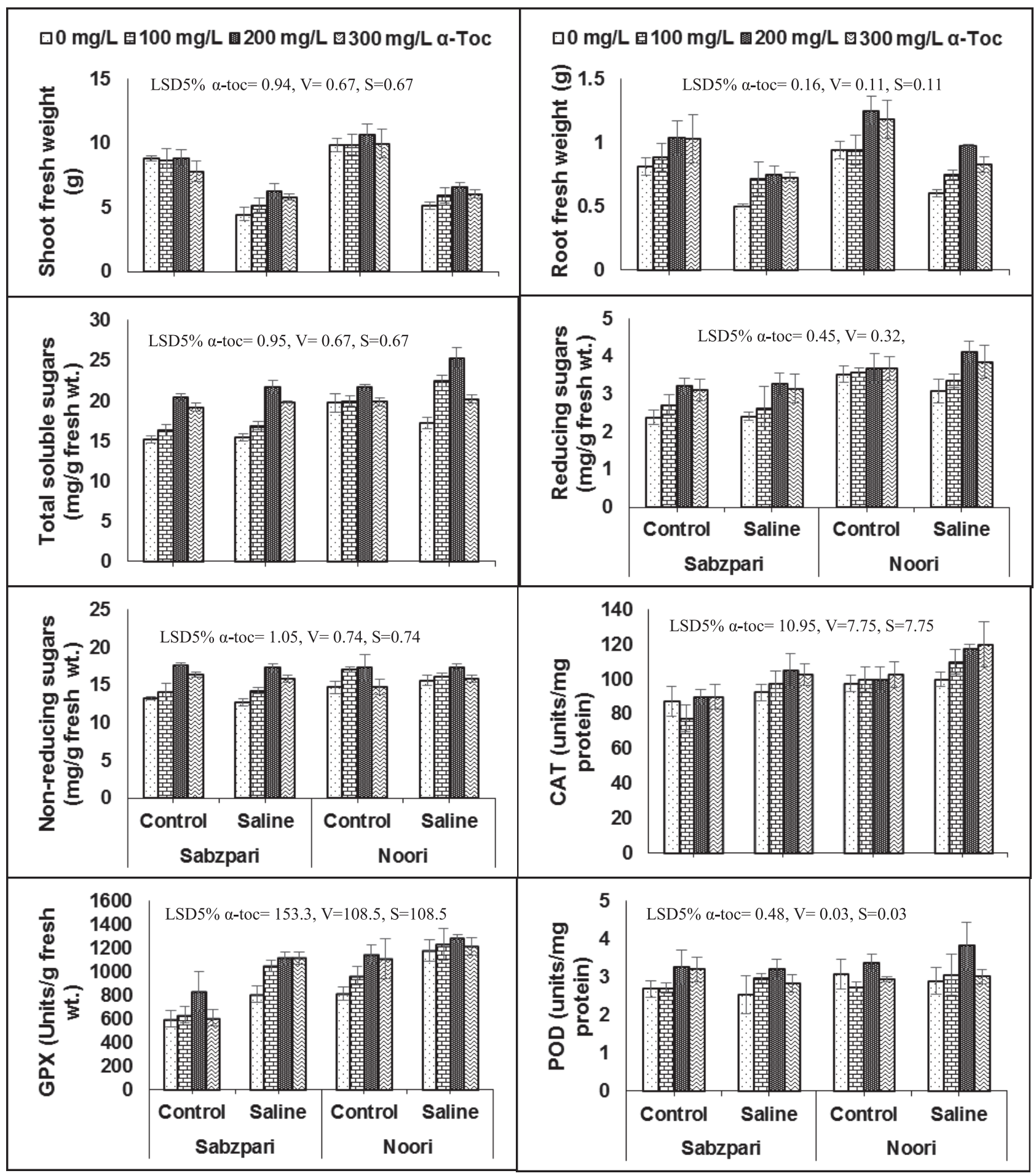

Fig. 1. Influence of $\alpha$-tocopherol seed priming on Growth, sugars and antioxidants activities of okra (Abelmoschusesculentus (L.) Moench) under control and saline condition. $\alpha$-toc, V, S stand for $\alpha$-tocopherol, varieties and salt stress levels. 
Guaiacol Peroxidase (GPX)

Protocol ascribed by Carlberg and Mannervik [31] was followed for the determination of GPX activities. Reaction assay was prepared, and optical density was taken at $470 \mathrm{~nm}$ for $1 \mathrm{~min}$ after every $30 \mathrm{~s}$.

\section{Protease}

Protease activity was recorded by following Drapeau et al. [32].

\section{Yield Parameter}

Yield attributes including number of pods/plant,fruit tissue free proline and glycinebetaine were determined

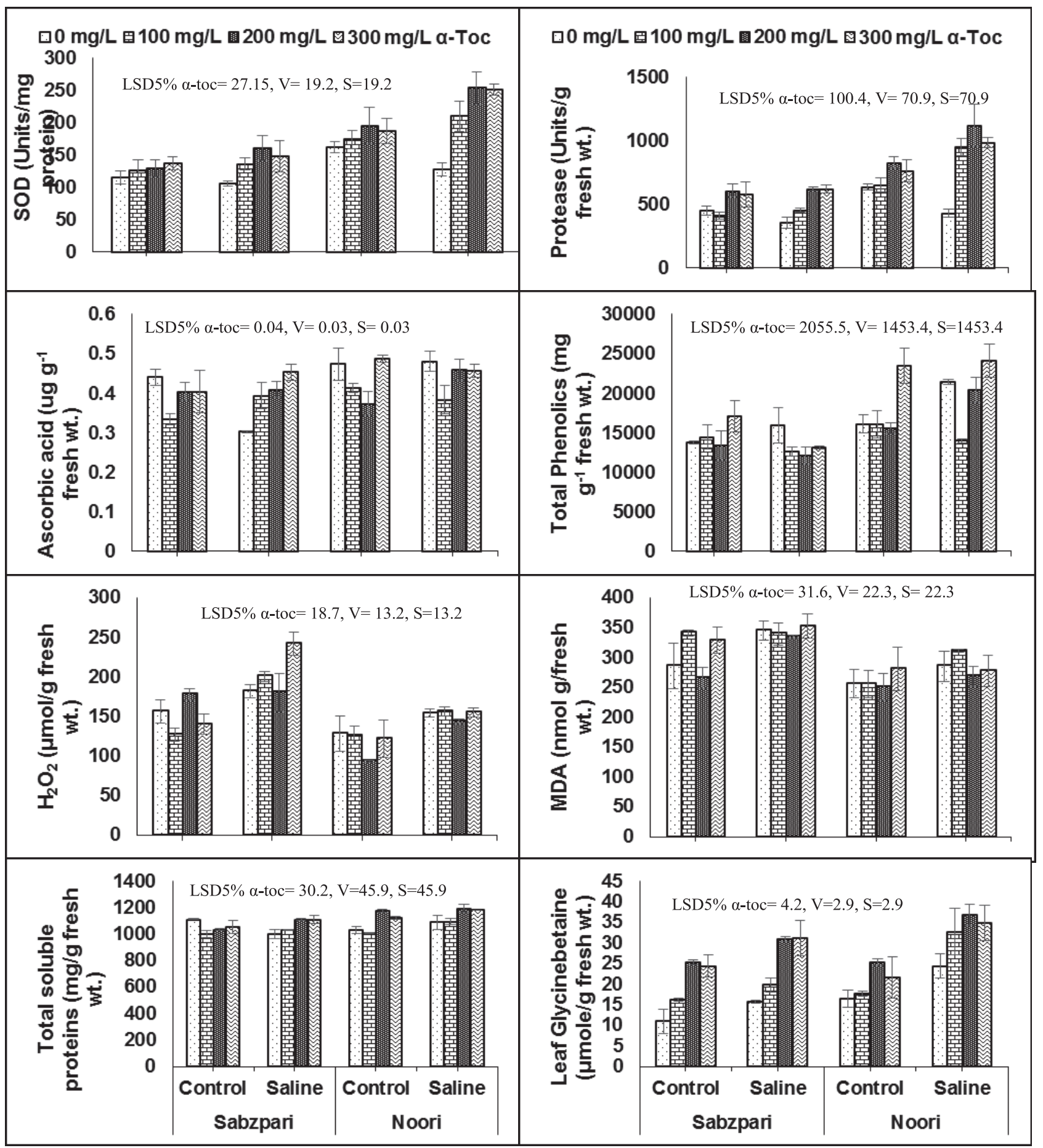

Fig. 2. Influence of $\alpha$-tocopherol seed priming on antioxidants activities, reactive oxygen species and organic osmolytes of okra (Abelmoschusesculentus (L.) Moench) under control and saline condition. $\alpha$-toc, V, S stand for $\alpha$-tocopherol, varieties and salt stress levels. 
Table 2. Analysis of variance (Mean squares) for antioxidants activities, reactive oxygen species, organic osmolytes and yield attributes of okra (Abelmoschusesculentus (L.) Moench) treated with different levels of $\alpha$-tocopherol as seed priming under control and saline conditions.

\begin{tabular}{|c|c|c|c|c|c|c|}
\hline Source & $\mathrm{df}$ & Ascorbic acid & Total phenolics & $\begin{array}{l}\text { Hydrogen peroxide } \\
\qquad\left(\mathrm{H}_{2} \mathrm{O}_{2}\right)\end{array}$ & Melondialdehye (MDA) & Total soluble proteins \\
\hline Varieties (V) & 1 & $0.037 * * *$ & $3.76^{* * *}$ & $26637.78^{* * *}$ & $41537.07 * * *$ & $8556.2 *$ \\
\hline Salinity (S) & 1 & $2.572 \mathrm{~ns}$ & $3492226.6 n s$ & $29272.48^{* * *}$ & $15892.26^{* *}$ & $38025^{* * *}$ \\
\hline $\begin{array}{l}\alpha \text {-tocopherol } \\
(\alpha \text {-toc })\end{array}$ & 3 & $0.013 * *$ & $79652122 * * *$ & $738.79 \mathrm{~ns}$ & $3689.34 \mathrm{~ns}$ & $4228 * * *$ \\
\hline $\mathrm{V} \times \mathrm{S}$ & 1 & $8.182 \mathrm{~ns}$ & $47523789 *$ & $926.02 \mathrm{~ns}$ & $637.96 \mathrm{~ns}$ & $7773.3^{*}$ \\
\hline $\mathrm{V} \times \alpha$-toc & 3 & $0.006 \mathrm{~ns}$ & $35637122 * *$ & $1365.78 \mathrm{~ns}$ & $381.76 \mathrm{~ns}$ & $1121.7 \mathrm{~ns}$ \\
\hline $\mathrm{S} \times \alpha$-toc & 3 & $0.008^{*}$ & 29723893* & $1677.06 \mathrm{~ns}$ & $1026.68 \mathrm{~ns}$ & $12000 * * *$ \\
\hline $\mathrm{V} \times \mathrm{S} \times \alpha$-toc & 3 & $0.013 * *$ & $7479830.7 \mathrm{~ns}$ & $2597.45^{*}$ & $2358.13 \mathrm{~ns}$ & $14938 * * *$ \\
\hline Error & 48 & 0.002 & 8360820.3 & 688.36 & 1975.87 & 1805.6 \\
\hline Source & $\mathrm{df}$ & $\begin{array}{c}\text { Leaf Glycine } \\
\text { Betaine }\end{array}$ & $\begin{array}{l}\text { Leaf Free } \\
\text { Proline }\end{array}$ & $\begin{array}{c}\text { Fruit Glycine } \\
\text { betaine }\end{array}$ & Fruit Free proline & Number of pods/plant \\
\hline Varieties (V) & 1 & $153.84 *$ & $13697 \mathrm{~ns}$ & $277.33 * *$ & $12604.07 *$ & $22.562 * * *$ \\
\hline Salinity (S) & 1 & $1555.1 * * *$ & $37616^{* * *}$ & $896.09 * * *$ & $12572.01 *$ & $49.0^{* * *}$ \\
\hline $\begin{array}{l}\alpha \text {-tocopherol } \\
(\alpha \text {-toc })\end{array}$ & 3 & $517.67 * * *$ & $22954 \mathrm{~ns}$ & $473.19 * * *$ & $5409.09 \mathrm{~ns}$ & $19.875^{* * *}$ \\
\hline $\mathrm{V} \times \mathrm{S}$ & 1 & $199.98 *$ & $28116 \mathrm{~ns}$ & $338.25 * * *$ & $6999.11 \mathrm{~ns}$ & $0.0625 \mathrm{~ns}$ \\
\hline $\mathrm{V} \times \alpha$-toc & 3 & $15.39 \mathrm{~ns}$ & $16097 \mathrm{~ns}$ & $9.65 \mathrm{~ns}$ & $585.12 \mathrm{~ns}$ & $0.3541 \mathrm{~ns}$ \\
\hline $\mathrm{S} \times \alpha$-toc & 3 & $11.28 \mathrm{~ns}$ & $7641.4 \mathrm{~ns}$ & $32.38 \mathrm{~ns}$ & $115.11 \mathrm{~ns}$ & $0.4583 \mathrm{~ns}$ \\
\hline $\mathrm{V} \times \mathrm{S} \times \alpha$-toc & 3 & $58.63 \mathrm{~ns}$ & $28733^{*}$ & $26.08 \mathrm{~ns}$ & $419.68 \mathrm{~ns}$ & $0.4375 \mathrm{~ns}$ \\
\hline Error & 48 & 35.29 & 8346.9 & 26.31 & 1988.41 & 1.8333 \\
\hline
\end{tabular}

$*, * *, * * *$ Significant at $0.05,0.01$ and 0.001 levels respectively; $\mathrm{ns}=$ non-significant.

by following the above-mentioned protocols for respective parameters.

\section{Statistical Analysis}

By following Snedecor and Cochran [33] analysis of variance (ANOVA) of data for all the parameters was calculated under three factor factorial under completely randomized design (CRD) using statistical software "Cohort". Means of the treatments were compared by LSD (least significant difference) at $\mathrm{p}<0.05$.

\section{Results}

Salinity markedly reduced shoot and root fresh weight of tested okra varieties. Both varieties differed significantly in term of these growth attributes as Noori was superior under saline and non-saline conditions. Seed priming with $\alpha$-tocopherol remarkably increased shoot and root fresh weight. Of various $\alpha$-tocopherol levels, 200mg L-1 had distinct effect in increasing shoot and root fresh biomass of saline and salinity free plants of both okra varieties (Table 1, Fig. 1).
Remarkable enhancement in the concentration of total soluble sugars and reducing sugars was recorded in both varieties of okra subjected to salt stress conditions. Although, no significant variation was recorded in nonreducing sugars content against salinity. In this attribute Noori was superior to Sabzpari. A prominent increase was observed in the concentration of all sugars related assessed parameters in both varieties of okra due to seed priming with $\alpha$-tocopherol (200 $\left.\mathrm{mg} \mathrm{L}^{-1}\right)$ under saline and saline free regimes (Table 1, Fig. 1).

Catalase (CAT) and guaiacol peroxidase (GPX) activities were markedly improved in okra varieties under saline stress. Okra variety Noori showed greater activities of these enzymes than Sabzpari under stressed and non-stressed settings. Alphatocopherol priming did not significantly affect the CAT activity whereas; GPX activity was significantly improved with $\alpha$-tocopherol seed priming in okra varieties (Table 1, Fig. 1). Both okra varieties showed non-significant performance in term of peroxidase (POD) activity. No significant effect was noted in POD levels following salt and $\alpha$-tocopherol application (Table 1, Fig. 1). Superoxide dismutase (SOD) activity in both varieties of okra plants was markedly enhanced under salinity treatment. SOD 
activities were higher in Noori than Sabzpari under salinity and salinity free conditions. The $\alpha$-tocopherol application as seed priming treatment also improved the activity of SOD (Table 1, Fig. 2).

Protease activity significantly enhanced following $\alpha$-tocopherol priming with and without salt stress application. Inclusively, the highest values were obtained at $200 \mathrm{mg} \mathrm{L}^{-1} \alpha$-tocopherol (Table 1, Fig. 2).

Salinity treatment non-significantly affected the ascorbic acid level and total phenolics content under saline and salinity free conditions. The okra variety Noori was superior to Sabzpari in these biochemical characteristics under saline and salinity free conditions. "Whereas, no significant effect was recorded for $\alpha$-tocopherol priming on proline content while, 200 and $300 \mathrm{mg} \mathrm{L}^{-1} \alpha$-tocopherol significantly enhanced GB content of okra varieties under stressed and nonstressed conditions (Table 2, Fig. 2)

Hydrogen peroxide $\left(\mathrm{H}_{2} \mathrm{O}_{2}\right)$ and malonedialdehyde (MDA) contents markedly enhanced under salt stress in the okra varieties. While, both varieties (Sabzpari and Noori) differed significantly in this attribute. Sabzpari accumulated more $\mathrm{H}_{2} \mathrm{O}_{2}$ and MDA than Noori under salinity and salinity free regimes. Seed priming with $\alpha$-tocopherol non-significantly affect MDA content and $\mathrm{H}_{2} \mathrm{O}_{2}$ in both varieties under stressed and non-stressed conditions (Table 2, Fig. 2).

Noori was superior in terms of total soluble proteins content, although reverse was true for Sabzpari. Total soluble proteins content markedly enhanced under saline regimes. Effect of seed priming treatment with $\alpha$-tocopherol (200 mg L-1and $300 \mathrm{mg} \mathrm{L}^{-1}$ ) was also significant in enhancing total soluble proteins content in saline and control settings (Table 2, Fig. 2).

Both okra varieties showed significant difference in terms of leaf and fruit glycinebetaine (GB) and total free proline contents. Noori accumulated more GB and free proline content as compared to Sabzpari under stressed as well as non-stressed regimes. Root medium salinity stress significantly enhanced GB and free proline contents in leaf and fruit tissues of okra. Whereas, seed priming with $\alpha$-tocopherol did not affect significantly on proline content whereas, seed priming with $\alpha$-tocopherol at 200 and $300 \mathrm{mg} \mathrm{L}^{-1}$ significantly enhanced GB content of okra varieties under stressed and non-stressed conditions (Table 2, Figs 2, 3).

Both okra varieties have shown significant difference in terms of productivity. However, Noori have produced more number of pods plant ${ }^{-1}$ than Sabzpari. Salinity reduced this yield attribute of both the varieties markedly. Whereas, seed priming with $\alpha$-tocopherolunder saline and non-saline treatments markedly enhanced number of pods in okra plants at $200 \mathrm{mg} \mathrm{L}^{-1}$ (Table 2, Fig. 3).

\section{Discussion}

In the current study, saline stress reduced growth of okra by reducing root and shoot fresh biomass. Growth is an important measure to assess salinity tolerance in plants and higher accumulation of toxic levels of $\mathrm{NaCl}$

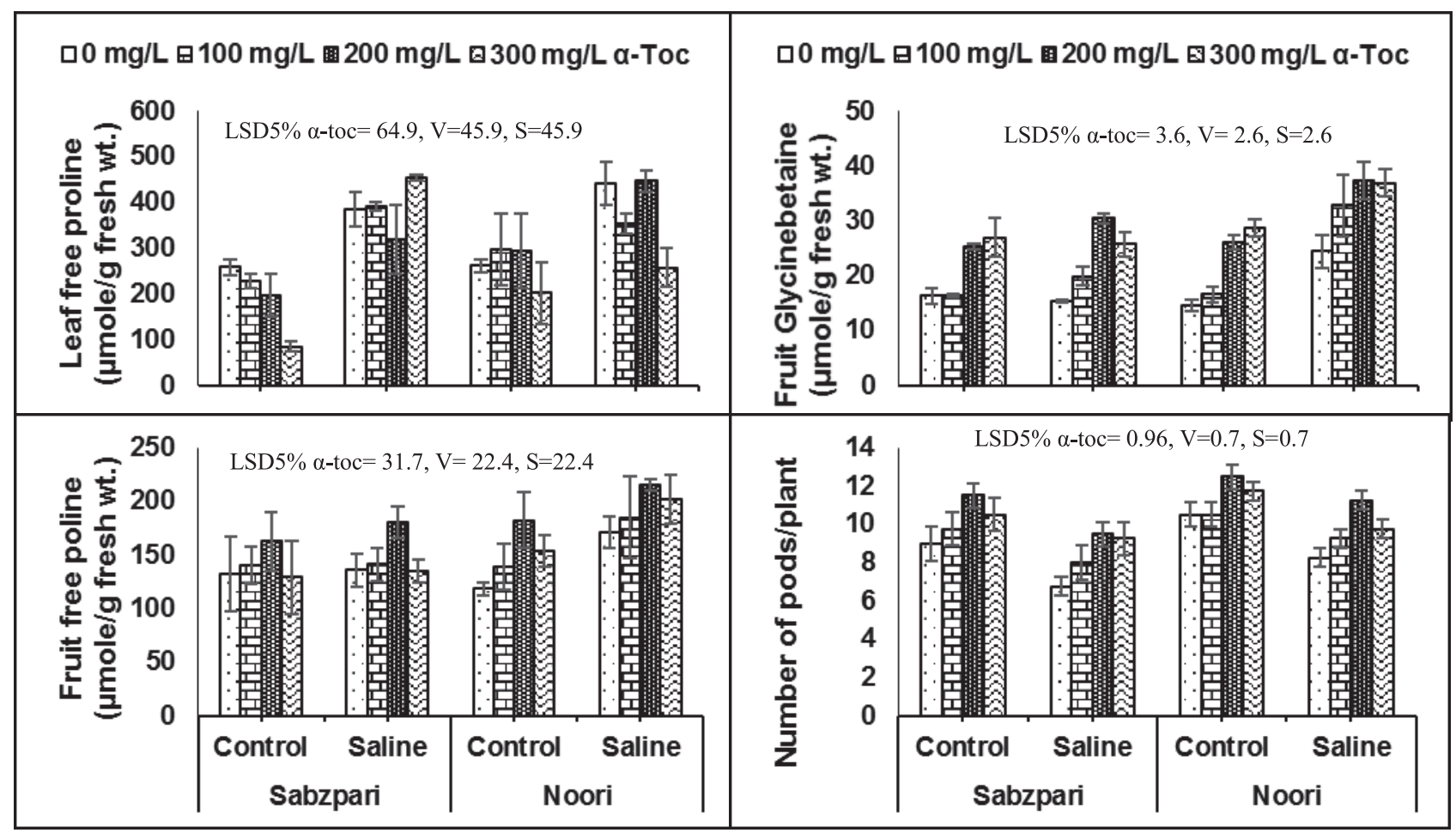

Fig. 3. Influence of $\alpha$-tocopherol seed priming on leaf free proline and yield attributes of okra (Abelmoschusesculentus (L.) Moench) under control and saline condition. $\alpha$-toc, V, S stand for $\alpha$-tocopherol, varieties and salt stress levels. 
hampers plant growth [34]. However, okra plants treated with $\alpha$-tocopherol have shown improvement in growth characteristics. This showed that alpha tocopherol supplementation increases plant growth by stimulation of various signaling factors involved in plant growth regulation [35]. As being sessile in nature, plants suffer from severe yield losses because of physiological level injuries under high salt levels [36]. In present investigation, salinity markedly reduced okra plants yield by reducing pods number. Reduction in yield might be attributed to hampered growth, photosynthesis and nutrient imbalance due to salt stress $[6,13]$. Seed priming with alpha tocopherol markedly enhanced yield of okra plants, as exogenously applied alpha tocopherol increased productivity by improving growth and nutritional balance [13].

Total soluble sugars and reducing sugars remarkably enhanced in tested okra varieties under salinity. A prominent increase was observed in sugars content in okra due to seed priming treatment with $\alpha$-tocopherol. Salinity tolerance may have been achieved due to accumulation of carbohydrates as protection mechanism [7]. Accumulation of sugars under abiotic stresses thought to be a symbol of membrane damage due to stresses induced ROS [37]. Alpha tocopherol improves higher buildup of carbohydrates [38]. To overcome brutal ROS effects, plants trigger induction of antioxidants [39]. Imposition of salinity stress significantly enhanced CAT, GPX, SOD and protease in the tested okra varieties. While, slight but nonsignificant enhancement was observed in the activity of POD. Enzymatic antioxidants play vital role to restore cellular redox balance by scavenging $\mathrm{ROS}\left(\mathrm{H}_{2} \mathrm{O}_{2}\right)$ [40]. Alpha tocopherol boosted the activities of CAT, SOD, GPX and POD non-significantly in current investigation whereas, marked acceleration have been recorded in the activity of protease. It is hypothesized that $\alpha$-tocopherol enhances endogenous levels of enzymatic antioxidants and protects the chloroplasts and cellular membranes from salinity induced ROS [41]. Higher concentration of leaf ascorbic acid was recorded in tested okra varieties under salt stress. The $\alpha$-tocopherol seed treatment significantly increased ascorbic acid content of both okra varieties under stressed and non-stressed conditions as; Ascorbic acid balances the osmotic homeostasis.

Salinity non-significantly enhanced total phenolics content in okra leaves. Priming with $\alpha$-tocopherol markedly increased total phenolics content in tested okra varieties. Total phenolics play vital role in plants by controlling plant metabolism.

In the current investigation, $\mathrm{H}_{2} \mathrm{O}_{2}$ and MDA were observed increased in tested okra plants. It is reported that, salinity triggers ROS production as by-products of cellular metabolism [42]. Furthermore, increased level of MDA indicates alterations in the functions and structure of cellular membranes due to peroxidation [43]. Priming of okra plants with $\alpha$-tocopherol nonsinificantly affect MDA and $\mathrm{H}_{2} \mathrm{O}_{2}$ under control and saline treatments, $\alpha$-tocopherol helps in stabilizing lipid membranes and scavenging ROS [15]. Total soluble proteins act as signaling molecules (sugar signaling) and osmolyte in plants during environmental strains. It is also hypothesized that higher levels of total soluble proteins increase SOD activities in plants thus, minimize adverse effects of ROS. Enhanced content of total soluble proteins was observed in tested okra plants due to salinity and, $\alpha$-tocopherol treatment increased total soluble proteins level in tested varieties, positive correlation exists between exogenous application of $\alpha$-tocopherol and proteins biosynthesis [38].

Salt stress markedly improved free proline content in the leaves and fruit tissue of tested okra varieties. Positive correlation exists between salinity stress responsive proteins and proline accumulation [44].

Improved production of compatible solute glycinebetaine (GB) is preferential mechanism adapted by plants to combat salinity and salt stress markedly increased GB level in the fruits and leaves of both okra varieties. Seed priming treatment of tested okra varieties with $\alpha$-tocopherol significantly enhanced GB level in leaves and fruit tissue of tested okra plants. Accumulation of GB is the preferential response of plants in salinity stress which stabilizes photosynthetic apparatus and pigments [45].

\section{Conclusion}

It has been concluded that salt stress adversely modulated various morpho-physiological traits of okra thus, alpha tocopherol seed priming treatment proved effective to combat salinity induced modulations by improving growth, yield, concentration of osmoprotectants (sugars, total soluble proteins and glycinebetaine) and activities of antioxidants (ascorbic acid, total phenolics, GPX, SOD and protease). It was also found that, application of alpha tocopherol at 200 and $300 \mathrm{mg} \mathrm{L}^{-1}$ proved more active and okra variety Noori performed better in all attributes.

\section{Conflict of Interest}

The authors declare no conflict of interest.

\section{References}

1. KASSI A.K., JAVED H., MUKHTAR T. Screening of Okra Cultivars for Resistance against Helicoverpaarmigera. Pakistan Journal of Zoology, 50, 91, 2018.

2. ESAN A.M., MASISI K., DADA F.A., OLAIYA C.O. Comparative effects of indole acetic acid and salicylic acid on oxidative stress marker and antioxidant potential of okra (Abelmoschusesculentus) fruit under salinity stress. ScientiaHorticulturae, 216, $278,2017$.

3. JEYAPRABA J., MAHENDRAN S., SUJIRTHA N. Growth physiology and membrane permeability of okra (Abelmoschusesculentus L.) seedlings as affected by 
salinity.International Journal of Plant and Soil Science, 9, $1,2016$.

4. KAUSAR F., SHAHBAZ M. Influence of strigolactone (GR24) as a seed treatment on growth, gas exchange and chlorophyll fluorescence of wheat under saline conditions. International Journal of Agriculture and Biology, 19, 321, 2017.

5. WU W., ZHANG Q., ERVIN E.H., YANG Z., ZHANG $X$. Physiological Mechanism of Enhancing Salt Tolerance of Perennial Ryegrass By 24-Epibarssinolide. Frontiers in Plant Science, 8, 1, 2017.

6. FAROOQ M., HUSSAIN M., NAWAZ A., LEE D.J., ALGHAMDI S.S., SIDDIQUE K.H.M. Seed priming improves chilling tolerance in chickpea by modulating germination metabolism, trehalose accumulation and carbon assimilation. Plant Physiology and Biochemistry, 111, 274, 2017.

7. SADIQ M., AKRAM N.A., ASHRAF M. Foliar applications of alpha-tocopherol improves the composition of fresh pods of Vignaradiata subjected to water deficiency. Turkish Journal of Botany 41, 244, 2016.

8. ALI Z., ASHRAF M., AL-QURAINY F., KHAN M.S., AKRAM N.A. Appraising drought tolerance in local accessions of sesbania (Sesbaniasesban (L.) Merril.) using biomass production, relative membrane permeability and photosynthetic capacity as selection criteria. Pakistan Journal of Botany, 47, 845, 2015.

9. LALARUKH I., SHAHBAZ M. Alpha-tocopherol induced modulations in morpho-physiological attributes of sunflower (Helianthus annuus) grown under saline environment. International Journal of Agriculture and Biology, 20, 661, 2018.

10. LALARUKH I., SHAHBAZ M. Response of antioxidants and lipid peroxidation to exogenous application of alphatocopherol in sunflower (Helianthus annuus L.) under salt stress. Pakistan Journal of Botany, 52, 75, 2020.

11. SADIQ M., AKRAM N.A., ASHRAF M., AL-QURAINY F., AHMAD P. Alpha-tocopherol induced regulation of growth and metabolism in plants under non-stress and stress conditions. https://doi.org/10.1007/s00344-01909936-7. 2019.

12. NAQVE M., SHAHBAZ M., WAHID A., WARAICH E.A. Seed priming with alpha tocopherol improves morphophysiological attributes of okra under saline conditions. International Journal of Agriculture and Biology, 20, 2647, 2018.

13. ORABI S.A., ABDELHAMID M.T. Protective role of $\alpha$-tocopherol on two Viciafaba cultivars against seawaterinduced lipid peroxidation by enhancing capacity of anti-oxidative system. Journal of the Saudi Society of Agricultural Sciences, 15, 145, 2016.

14. JIN S., DANIELL H. Expression of $\gamma$-tocopherol methyltransferase in chloroplasts results in massive proliferation of the inner envelope membrane and decreases susceptibility to salt and metal-induced oxidative stresses by reducing reactive oxygen species. Plant Biotechnology Journal, 12, 1274-, 2014.

15. SEMIDA W.M., TAHAR.S., ABDELHAMID M.T., RADY M.M. Foliar-applied $\alpha$-tocopherol enhances salt-tolerance in Viciafaba L. plants grown under saline conditions. South African Journal of Botany, 95, 24, 2014.

16. JI C.Y., KIM Y.H., KIM H.S., KE Q., KIM G.W., PARK S.C., LEE H.S., JEONG J.C., KWAK S.S. Molecular characterization of tocopherol biosynthetic genes in sweet potato that respond to stress and activate the tocopherol production in tobacco. Plant Physiology and Biochemistry, 106, 118, 2016.

17. HOAGLAND D.R., ARNON D. The water culture method for growing plants without soil. California Agricultural Experimental Station Circular No. 347, 1, University of California, Berkeley, 1950.

18. DUBOIS M., GILLES K., HAMILTON J.K., REBERS P.A., SMITH F. Colorimetric determination of reducing and nonreducing saccharides.Nature, 168, 167, 1951.

19. MILLER E.L. Evaluation of foods as sources of nitrogen and amino acids.Proceedings of the Nutrition Society, 32, 79, 1973.

20. AINSWORTH E.A., GILLESPIE K.M. Estimation of total phenolic content and other oxidation substrates in plant tissues using Folin-Ciocalteu reagent.Nature Protocols, 2, 875, 2007.

21. MUKHERJEE S.P., CHOUDHURI M.A. Implications of water stress-induced changes in the levels of endogenous ascorbic acid and hydrogen peroxide in Vigna seedlings. PhysiologiaPlantarum, 58, 166, 1983.

22. ALEXIEVA V., SERGIEV I., MAPELLI S., KARANOV E. The effect of drought and ultraviolet radiation on growth and stress markers in pea and wheat.Plant, Cell and Environment, 24, 1337, 2001.

23. HEATH R.L., PACKER L. Photoperoxidation in isolated chloroplasts: I. Kinetics and stoichiometry of fatty acid peroxidation. Archives of Biochemistry and Biophysics 125, 189, 1968.

24. DHINDSA R.S., PLUMB-DHINDSA P., THORPE T.A. Leaf senescence: correlated with increased levels of membrane permeability and lipid peroxidation, and decreased levels of superoxide dismutase and catalase. J. Exper. Bot., 32, 93, 1981.

25. DHINDSA R.S., PLUMB-DHINDSA P., THORPE T.A. Leaf senescence: correlated with increased levels of membrane permeability and lipid peroxidation, and decreased levels of superoxide dismutase and catalase. Journal of Experimental Botany, 32, 93, 1981.

26. BRADFORD M.M. A rapid and sensitive method for the quantitation of microgram quantities of protein utilizing the principle of protein-dye binding.Analytical Biochemistry, 72, 248, 1976.

27. BATES L.S., WALDREN R.P., TEARE I.D. Rapid determination of proline for water stress studies. Plant Soil, 39, 205, 1973.

28. GRIEVE C.M., GRATAN S.R. Rapid assay for the determination of water soluble quaternary ammonium compounds. Plant Soil, 70, 303, 1983.

29. GIANNOPOLITIS C.N., RIES S.K. Superoxide dismutase. I. Occurrence in higher plants. Plant Physiology, 59, 309, 1977.

30. CHANCE M., MAEHLY A.C. Assay of catalases and peroxidases. Methods in Enzymology, 2, 764, 1955.

31. CARLBERG I., MANNERVIK B. Glutathione reduct aseassay. Methods in Enzymology Academic Press, Orlando, 113, 484, 1985.

32. DRAPEAU P., AMANT S.L., BUSS R.R., CHONG M., DEARMID M.R.J. Brustein. DREB1A and DREB2A. Plant Physiology, 150, 1972, 1974.

33. SNEDECOR G.W., COCHRAN G.W. Statistical Methods. $7^{\text {th }}$ Edition. Lowa State University Press, Ames, LOWA, 1980.

34. SARWAR Y., SHAHBAZ M. Modulation in growth, photosynthetic pigments, gas exchange attributes and inorganic ions in sunflower (Helianthus annuus L.) 
by strigolactones (gr24) achene priming under saline conditions. Pakistan Journal of Botany, 52, 23, 2020.

35. HOUSTON K., TUCKER M.R., CHOWDHURY J., SHIRLEY N., LITTLE A. The plant cell wall: a complex and dynamic structure as revealed by the responses of genes under stress conditions. Frontiers in Plant Science, 7, 2016.

36. SARWAR Y., SHAHBAZ M. GR24 triggered variations in morpho-physiological attributes of sunflower (Helianthus annuus) under salinity. International Journal of Agriculture and Biology, 21, 34, 2019.

37. FRITSCHE S., WANG X.X., JUNG C. Recent advances in our understanding of tocopherol biosynthesis in plants: an overview of key genes, functions, and breeding of vitamin E improved crops. Antioxidants (Basel) 6, 20, 2017.

38. ALVES L.C., LLERENA J.P.P., MAZZAFERA P., VICENTINI R. Diel oscillations in cell wall components and soluble sugars as a response to short-day in sugarcane (Saccharum sp.). BMC Plant Biology, 19, 215, 2019.

39. MUNOZ P., MUNNE-BOSCH S. Vitamin E in plants: biosynthesis, transport, and function. Trends in Plant science, https://doi.org/10.1016/j.tplants.08.006. 2019.

40. TARIQ A., SHAHBAZ M. Glycinebetaine induced modulation in oxidative defense system and mineral nutrients of sesame (Sesamumindicum L.) under saline regimes. Pakistan Journal of Botany, 52, 775, 2020.
41. SUÁREZ-JIMÉNEZ G.M., LÓPEZ-SAIZ C.M., RAMÍREZ-GUERRA H.E., EZQUERRA- BRAUER J.M., RUIZ-CRUZ S., TORRES-ARREOLA W. Role of endogenous and exogenous tocopherols in the lipid stability of marine oil systems: a review. International Journal of Molecular Sciences 17, 1, 2016.

42. NXELE X., KLEIN A., NDIMBA B.K. Drought and salinity stress alters ROS accumulation, water retention, and osmolyte content in sorghum plants. South African Journal of Botany, 108, 261, 2017.

43. SURÓWKA E., POTOCKA I., DZIURKA M., WRÓBEL-MAREK J., KURCZYŃSKA E., ZUR I., MAKSYMOWICZ A., GAJEWSKA E., MISZALSKI Z. Tocopherols mutual balance is a key player for maintaining Arabidopsis thaliana growth under salt stress. Plant Physiology and Biochemistry, 156, 369, 2020.

44. KRUK J., SZYMANSKA R., NOWICKA B., DLUZEWSK J. Function of isoprenoid quinones and chromanols during oxidative stress in plants. New Biotechnology, 33, 636, 2016.

45. MANSOUR M.M.F., ALI E.F. Evaluation of proline functions in saline conditions. Phytochemistry, 52, 68, 2017. 